\title{
Governed by technology? Urban management of broadband and 3G systems in Sweden
}

\author{
Jenny Palm and Elin Wihlborg
}

\section{Linköping University Post Print}

\section{Tweet}

N.B.: When citing this work, cite the original article.

This is an electronic version of an article published in:

Jenny Palm and Elin Wihlborg, Governed by technology? Urban management of broadband and 3G systems in Sweden, 2006, The Journal of urban technology, (13), 2, 71-89.

The Journal of urban technology is available online at informaworldTM:

http://dx.doi.org/10.1080/10630730600872054

Copyright: Taylor \& Francis (Routledge): SSH Titles http://www.routledge.com/

Postprint available at: Linköping University Electronic Press

http://urn.kb.se/resolve?urn=urn:nbn:se:liu:diva-46001 


\title{
Governed by technology? \\ Urban management of broadband and $3 G$ systems in Sweden
}

\author{
Jenny Palm \\ Department of Technology and Social Change \\ Linköping University \\ S-581 83 Linköping \\ Sweden \\ jenpa@tema.liu.se \\ $+46(0) 13285615$
}

Elin Wihlborg

Department of Political Science

School of Management

Linköping University

eliwi@eki.liu.se

+46(0) 13281578 


\section{Governed by technology?}

\section{Urban management of broadband and $3 G$ systems in Sweden}

\section{Introduction}

Sweden is often ranked highly in international comparisons of IT and mobile phone penetration, and its infrastructure for electronic communication is good and is continuously improving. A historical comparison of telecommunication, railways, post and road infrastructures in Sweden shows a dominant characteristic of overreaching state responsibility opening for local and private interests. Kaijser (1994) argues that this regime is so strong that it is motivated to regard it as a Swedish model. Now, specific policies addressing the information society have been integrated into this regime. Thus, any discussion of Swedish policies regarding the information society will have general implications.

The two most recent IT infrastructural changes_-broadband and third-generation mobile phones $(3 \mathrm{G})$ - have been organized differently at the national level in Sweden and thus also implemented differently at the local (urban and rural) level. The spatial based system of broadband is seen as a municipal responsibility, while the flexible and mobile system for 3Gtelephone systems are mainly market focused.

This article focuses on the interplay between how technological innovations are implemented and the structure of the technological design, by analyzing broadband and $3 \mathrm{G}$ infrastructure at a local level in Sweden. The article emanates from the analysis of large sociotechnical systems in a policy context to highlight the fact that local systems are established within local power relations. Thereby we develop the sociotechnical concepts system builders, critical problems, and technology style to anchor them to an urban context.

The aim is to analyze how and why broadband and 3G infrastructure are implemented differently in Swedish municipalities (both urban and rural). The article is a re-analyze of our field studies and based on the sociotechnical concepts system builders, critical problems, and technology style. Our main research questions are:

- How is the introduction of broadband and $3 \mathrm{G}$ integrated in the Swedish model of infra structural regimes?

- What arises as critical problems during implementation and how are these locally handled?

- Are there any connections between technical systems design and it's policy? 
The first part of the article introduces a combined theoretical approach and three analytical concepts: system builders, critical problems, and technology style. The second part gives an overview of the two technological systems $-3 \mathrm{G}$ and broadband. The description of national policies should be considered as a background for the analysis of local implementation. The third part of the paper analyzes the two technological systems through the theoretical model. Finally, the concluding remarks tie the discussion together.

The analysis are based on three intensive municipal-level field studies regarding IT and energy in broad terms, and one more extensive field study regarding $3 G(12 ; 18 ; 19)$. The research included examination of written primary sources, such as investigations, minutes, and notes, as well as field work, such as interviews with local actors (e.g., local politicians, municipal officials, and representatives of the local energy company), private firms, and other related organizational bodies. Our analysis of the national context is based on examination of government bills and Swedish Government Official Reports (SOU). We used case studies to illustrate our argument regarding the differences between broadband and $3 \mathrm{G}$ in terms of policies and implementation in Swedish municipalities. The case studies are thus not analyzed perse.

\section{Sociotechnical systems in local contexts}

As sociotechnical system, IT systems (in this context, broadband and 3G systems) consist of the technical components, individual actors and organizations, legal frameworks, and institutional and political structures. The system is interwoven with the societal context, cultural values, and specialized professional know-how by which it operates. The term sociotechnical indicates that we are including the social and human as well as technical components in the system and considering them to be interdependent. Sociotechnical systems are, from this perspective, regarded as seamless webs of tightly interconnected components. Changes made to one part of the system must be adjusted to the other existing parts to obtain a working whole. According to this view, governing the innovations and policies that affect technology requires both social and technical knowledge of the system $(6 ; 7 ; 17 ; 20)$.

The theory of sociotechnical systems includes several central concepts that have set trends in analyzing the development of large technical systems, in an attempt to capture the interplay among the technical and social aspects of a system. Three central concepts—system builders, critical problems, and technology style - have appeared as useful for identifying and explain processes of broadband and $3 \mathrm{G}$ provision. 
System builders are actors driving the development and construction of the system. They also operate the system and must resolve the critical problems that occur when one part of the system does not develop in step with the rest, threatening the system's continued expansion. During these periods the system stagnates until the problem is solved. Technology style emphasizes that technical systems are human constructs, interacting with their societal environments, and therefore subject to variations between municipalities.

\section{System builders}

System builders are the critical actors of the process and thus of the management of building sociotechnical systems. Their participation is crucial for the development of the system. Successful system builders, such as inventors, engineers, managers, and financiers, have a clear vision of the interconnectedness of the whole system and of what is required to reach the goal (6). These actors are formally autonomous, making their decisions and acting according to their own criteria. "System-building is a messy process of complex, multifaceted problemsolving” (17, p. 89). System builders are central to making sense of the process. Their actions and capacity to unite different interests are crucial for making changes to the system. System builders strive to control the system by using resources that are available for them.

The system builder's personal competence is crucial. Their most important resource is often their technical and social knowledge. They have to transform their knowledge into action to create meaningful intentional order $(6 ; 11 ; 12 ; 16)$. Economic resources-money or time invested in the process-are crucial and transformed by the system builder's competence to contextualize them into specific objective in the actual policy making process.

\section{Critical problems}

Critical problems appear when one part of a system does not develop in step with the rest, threatening the system's continued expansion. The problem must be solved before the system can resume progress toward its internal and the system builders' goals. Critical problems must be identified and solved by the system builders (6;17), who must be able to redeploy resources to this end (10). As stated above, resources are not only economic, but also include social assets such as institutions, knowledge, experience, and social networks and contacts.

Critical problem have in earlier studies been identified as for example geographic conditions limiting the scope for expansion of infrasystems (5a) and local resistance related to the siting of renewable energy facilities (10a). 


\section{Technology style}

The concept of technology style emphasizes that both technical systems and their applications are human constructs. They interact with their environment and are subject to varied influences, characterized by specific contextual and circumstantial factors. A wide range of local conditions external to the technology affects its style, for example geographical, political, economic, social, legal, cultural, and historical conditions (6). Technological style is always time-spatial delimited, and grounded in the social and physical context in which it is formed. The geographical context has to be problematized when the focus is on municipalities, since they are both organizational and specific physical-geographical entities. Technical style is contextual and thus dependent on what the actors experience as locally constraints and available resources both physical and social (5a; 19).

These three analytical concepts are all identified within a local context. The local context is both physical and comprises social order formed by accessible resources and experienced constraints, dependent on the purpose of the project $(9 ; 18)$. Context can be seen on different levels national, local, and even within a neighborhood, but the larger one define more limited contexts. System builders use local available resources and resolve constraints. The local order defines what is considered as a critical problem and why. The technology style is a specific aspect of the context when it comes to the system design.

\section{National policies_-setting the context}

Swedish information society policies have a strong aim to be in the technological forefront while guaranteeing equal distribution of access to and use of any new technology. There is an interplay between national and local policies, even if the national regimes mainly establish a framework of possibilities and constraints for local policy initiatives.

Both $3 \mathrm{G}$ and broadband systems are driven by the demands or, more accurately, the expected demands of users and their potential use. Such demands entail a certain technical capacity, and both broadband and $3 \mathrm{G}$ are defined by a bandwidth of over $2 \mathrm{MB} / \mathrm{s}$.

\section{$3 G$-a market solution}

The infrastructure for the European $3 \mathrm{G}$ mobile telephone system, also called the universal mobile telecommunications system (UMTS), is now being built and is based on a vision of a global standard for third-generation mobile communication systems. UMTS is the thirdgeneration mobile telephone system and is the successor to GSM. Users of UMTS phones will have access to computerized communications and multimedia, as well as ordinary voice 
telephone service. UMTS should be able to offer multimedia and data transfer services (with speeds of up to $2 \mathrm{MB} / \mathrm{s}$ ). In Sweden, licenses to provide $3 \mathrm{G}$ service were granted by PTS to four operators: Europolitan, HI3G, Orange, and Tele2. This is a mainly market based model.

The needed infrastructure consists of base stations, transmitters/antennas, and masts carrying the base stations and transmitters/antennas. In urban areas antennas are placed about 250 meters apart, while in rural areas they can be almost $10 \mathrm{~km}$ apart. The antennas are put on masts or buildings; roofs, facades, and radio and TV masts are examples of existing places or sites for antennas. In urban areas it is relatively easy to find new sites, but in rural areas new masts often have to be purpose built. The estimated demand for purpose-built masts was about 10,000 in 2005. Building a mast requires a building permit issued by the municipality, in accordance with the Planning and Building Act (15). An environmental assessment conducted by the county administration board is normally also necessary. When antennas are mounted on facades or other parts of buildings, the requirement for a building permit may be waived, depending on the results of dialog between municipalities, the building owner, and the operator.

Operators initially agreed to provide coverage of $99.8 \%$ of the population by December 31 , 2003 (1). However, all operators have applied to PTS for extended deadlines to achieve full coverage. The delays are mainly due to problems obtaining municipal building permits, and in view of this, the law was changed to facilitate issuance of building permits for masts (3). As of December 1, 2004, 3G service was available to 85 percent of the Swedish population; in seven municipalities everyone could access $3 \mathrm{G}$ service, while in three municipalities there was no coverage (13). The operators do not present any statistics on numbers of subscribers.

\section{Broadband infrastructure}

Broadband is high-speed computer networking connection, encompassing several technical choices. The most common technical solution is fiber optic cables, which were also considered the most "future safe" solution by the government's official IT commission (19942003). Radio and satellites are other means of communication potentially involved in broadband infra structure. When the governmental bill An information society for all (2) was designed there was also an idea of exploiting potential for increased bandwidth of TV cable networks or even the electrical grid; however, these have not developed into useful technological choices. Increased telephone line capacity was however sold in the name of "broadband," even though it almost never reached the defined capacity of $2 \mathrm{MB} / \mathrm{s}$. The main technological choice that was developed was the installation of new optic-cables. 
Building a national broadband infrastructure had been on the agenda for several years before Parliament approved the bill, in September 2000 (2). Public debate was initially driven by several private companies that were willing to build the necessary infrastructure. The parliamentary decision, however, favored a national scheme implemented by the municipalities, similarly to the style of Swedish new technology implementation developed for railways and telephones in the late nineteenth century (11).

The broadband infrastructure in Sweden is divided into four levels. The most basic level is the national backbone network, handled by the state-owned company Svenska Kraftnät. The second level is the regional network connecting Sweden's various regions; the municipalities have to provide and finance this level, except if a market actor has already done so. However, the local networks and access networks can be arranged in different ways. The main intention was that these levels should be privately owned and run, but there are also completely municipally owned local networks. These levels are still lacking in areas without broadband access. The interest of market actors has also declined, and the most recent governmental bill concerning IT $(5$, p. 51) highlights the importance of coordinating the different types of IT infrastructure development.

\section{Municipal implementation}

According to the Swedish constitution, the municipalities have an inclusive independence and exclusive authority to handle physical planning. This is a crucial prerequisite for the exercise of their policy-making and governance in the local context. The municipal council has the exclusive decision making power, defining comprehensive policies. The administrative body of the municipality includes several departments and committees, transforming policies into specific decisions. Therefore they can give a contradictory impression.

\section{$3 G \longrightarrow$ municipalities as an institutional context}

The decision to allow installation of a base station at a specific place is often a matter for the municipal building committee, even if it can be delegated to officials at the building office. To this end, PTS has informed municipalities of their responsibilities and has designed guidelines. Even though PTS lacks the authority to compel municipalities to handle IT issues in any specific way, it argued for the rapid introduction of $3 \mathrm{G}$ infrastructure in the interests of almost total national coverage, and thus emphasized the importance of a rapid construction planning process. The municipalities were requested to investigate cooperation and coordination between the operators. 
Managing building permit granting in municipalities is a two-fold process. First, the installation of antennas in the city requires the issuance of building permits if the antennas affect the building substantially. The need for such permits is determined on a case-by-case basis. The strong regional independence in Sweden creates possibilities for different management approaches, from total lack of preparedness to formal "round table conferences" with the actors (1). Second, in planning areas outside population centers building permits are required for masts and their placement, but not for the antennas.

For example, in the municipality of Linköping (at 130000 inhabitants, the fifth-largest city in Sweden), the policy is that new masts should not be constructed. Antennas should instead be mounted on existing masts, high buildings, and other constructions, and there must be coordination and cooperation between operators in the establishment of new masts. Linköping municipality has also through its exclusive planning power decided on one-specific "mast-free zone" with a radius of five kilometers. Linköping has already received around 70 building permit applications for masts; of these, 30 have been approved. The building office estimated that they will approve another 3-4 masts, for a total of around 35 masts. A survey of existing antennas that did not require building permits for their construction has not been conducted in Linköping.

The main reason for rejecting a building permit application has generally been that the mast would be built outside the area designated for masts in the detailed plan. Some applications have been rejected on the grounds of excessive impact on the landscape or important cultural landmarks.

The possibility of rejecting an application because of concern regarding radiation emission is very restricted, according to the Building Permit Act. By law, the risks posed by radiation are to be considered if the measured radiation exceeds the threshold value established by the Swedish Radiation Protection Authority (SSI) and WHO. SSI and other authorities have concluded that there are no proven medical risks associated with the base stations. At the local level, this has been interpreted to mean that the risks of radiation are not to be considered at the municipal level and should not influence the processing of a building permit. Opponents have criticized this restrictive interpretation of the Building Permit Act; they claim that the Environmental Code (16) should be applied together with the Building Permit Act (15) in every building permit application (14). 


\section{Broadband as a municipal responsibility}

The intention of Governmental Bill 1999/2000:86, despite its lofty ambitions regarding the information society, was a limited and quite complicated subsidy scheme for building broadband infrastructure in areas where market actors were not expected to provide the infrastructure independently (i.e., where they saw no potential for profits). There was an obvious difference between urban and rural areas. To gain access to governmental subsidies, municipalities had to formulate local IT infrastructure plans that had to be approved by the county council (länsstyrelsen). When a plan was approved and private and public co-funding was confirmed, a municipality could then apply for the governmental subsidies.

At the time, many rural areas, especially in northern Sweden, were still receiving essential funding from the European Structural Funds. Such funding explicitly demands local cofunding, from both private and public actors. In some municipalities this facilitated the rapid establishment of broadband infrastructure. The national subsidy scheme was considered to be the one-third share of local public co-funding, complemented by EU and local private funding that provided the other two thirds. This idea of partial fiscalization was strong, and in combination with the municipalities' exclusive planning power, broadband infrastructure came to be considered almost completely a municipal autonomy administrative issue. Only in urban growth areas where private firms saw economic potential in providing broadband was the municipalities' ascendancy challenged.

A creative way to provide the one third of local private funding in rural areas is to integrate and rely on the strong community groups in the villages (byalag). These rural community groups are often involved in issues regarding local services, such as schools and shops. In the broadband case, these groups often got involved, since national policies considered and/or constructed access to broadband as a pre-requisite for economic development. The unpaid voluntary work done by villagers could be accounted for in the budget as the last third of funding, and considered as a private contribution. This was accepted even though the donated labor itself never was transformed into market value. Thus, today Swedish rural areas can boast impressive broadband coverage, far more extensive than the $3 \mathrm{G}$ coverage.

\section{Urban management of broadband and 3G}

The differences in the implementation of broadband and 3G in Sweden will now be examined as changes in the urban management of sociotechnical systems, using the three theoretical concepts as described above. 


\section{System builders}

In establishing the infrastructure for broadband and $3 \mathrm{G}$ we have identified three broad categories of actors: operators, government, and municipalities. The government, through the administrative body, the National Post and Telecom Agency (PTS), requires full coverage by the $3 \mathrm{G}$ system as soon as possible. The operators want to receive good economic prerequisites and an advantageous and profitable market position. The municipalities, and more specific the building administration, building committee and municipal council, are not key actors in the $3 \mathrm{G}$ establishment in the same way as they were in establishing the broadband system. Instead, the $3 \mathrm{G}$ system has been built with the national government and the operators acting as system builders. The municipalities' task has been to ensure that the building permit process runs smoothly and does not delay the schedule to establish Sweden as an IT leader.

When municipalities are responsible for building the broadband infrastructure, they act as the main system builder integrating the other actors and various interests. The most crucial system builders in broadband development are the market actors, since they cooperate closely with municipalities to propose system solutions, also often building them as well. These actors create an action space between the market and the local administrative bodies. This quasi-market was especially apparent in the rural areas, where national subsidies and European co-funding were more accessible and extensive than in urban areas, where market solutions were expected to dominate. Policy measures created the quasi-market so as to integrate market actors and their knowledge and economic resources. In rural areas, the village community groups acted as the system builder, often organizing and uniting various interests and mobilizing support and even labor from local citizens.

The companies and their system builders often possessed unique technical competence that the municipality needed. This was obvious in one small and remote rural municipality we studied. Here, one resident had long hoped to telecommute as an employee of a large international company with a regional office about 400 kilometers away. He saw the opportunity to engage the municipality as a local customer, and his company got the mandate to plan the local IT infrastructure. This man offered great personal resources and motivation, since he could use his local contacts and recruit colleagues locally. When the plan was approved by the county council and funding was secured from national subsidies and cofunding through the European Structural Funds, the same company was given the task of organizing and implementing the new infrastructure system in cooperation with the local community. Thus a single person with great personal competence and technical knowledge 
became the system builder, and more or less defined the technical design of broadband in the rural area.

Many municipalities also own an energy company, which often were given the responsibility of handling broadband implementation, for example in larger municipalities such as Gothenburg and Linköping. Using municipal companies for such market-related changes was beneficial when it came to making agreements with other firms. The municipality could act as a market actor, while still upholding the values of democracy and equality (though promoting these values seldom produced anything more concrete than a mention in company policy). Hence, an energy company could become the local broadband system builder when it possessed the appropriate capacities.

The action space of system builders is a central analytical point and depends on accessible resources and experienced constraints. In all broadband cases, local technological knowledge became a defining resource, used differently depending on the specific context. When local energy companies possessed such competence, they often became the system builder. In other cases, the village community groups played that role, becoming a system builder so as to develop resources. However, local knowledge was not used in $3 \mathrm{G}$ development, and thus few local system builders were apparent in this process; neither was the issue of $3 \mathrm{G}$ development affected by the exclusive planning power of the municipalities.

Municipalities are less responsible for implementation of $3 \mathrm{G}$ and hence have been less directly involved and outspoken than was the case with broadband. Since government policies regarding $3 \mathrm{G}$ were rooted in the notion of creating a market, the municipalities' action space is different here. They handle applications for building permits, according to their jurisdiction; as well, they are assessed by the national government regarding the required level of coverage and schedule of system development—two obvious problems.

The establishment of a $3 \mathrm{G}$ system is a matter of national interest. This pressures municipalities not to oppose, but rather to expedite permit applications. With $3 \mathrm{G}$ development, municipalities are not system builders and have no occasion to offer incentives or directly impede technical system development. Empirical studies of the municipal handling of $3 \mathrm{G}$ have concluded that many municipalities felt pressured to prioritize $3 \mathrm{G}$ issues at the expense of others (1).

\section{Critical problems}

There is an obvious difference in the number and handling of perceived critical problems regarding $3 \mathrm{G}$ and broadband. Broadband experienced few critical problems, probably because 
of the clear legislative guidelines and the fact that implementation mainly happened within the confines of municipalities.

In the $3 \mathrm{G}$ case, time has been emphasized by the operators, as they fell behind schedule and had to postpone system completion. One reason cited by both the market actors and the government was the slow municipal process of building permit issuance. The municipalities disagreed with this criticism, and claimed that the slow processing often stemmed from poorly prepared applications, which were missing important information. In establishing the 3G system, the municipalities were not expected to be system builders. The national government expected that the municipalities should not themselves constitute a critical problem for system development. Indeed, municipalities have usually striven to satisfy that expectation, by ensuring that $3 \mathrm{G}$ capacity is established smoothly.

The most obvious critical problem in the municipalities has been the radiation issue. Though municipalities are constrained by the Building Permit Act in their ability to reject an application because of radiation risks, municipalities have circumvented this in various ways. In the Stockholm region, though the most visible protests concerned fear of radiation, building permits were issued anyway. In Trelleborg, a medium-sized municipality on the south coast, building permits were refused with reference to health issues. Similarly, in another mediumsized municipality, Motala, the planning and environmental committee rejected building applications, referring to the radiation risk. These were regarded as legal decisions, despite the fact that municipalities cannot explicitly consider such matters when evaluating building permit applications. PTS has recommended that municipalities should make decisions based only on the Building Permit Act and not with reference to the aims of the Environmental Code.

Most building permits have prompted complaints from residents concerning the risks of radiation, but this has never been a reason for application rejection there. The municipal administration preferred to influence the operators through communication, even though it lacked legally binding instruments. Nevertheless, this "soft management" approach has succeeded almost every time in achieving a 300-meter "respect distance" between transmitters and nearby residents.

Radiation is obviously an issue that concerns and engages citizens. They do not want a mast to be built nearly, even though competent authorities agreed that transmitters pose no scientifically demonstrated health risks. Linköping has tried to assuage citizen concerns by implementing a "mast-free zone" and keeping 300 meters between masts and residential buildings. This compromise handles the authorities' assertion that there is no radiation risk, 
and partly assuages citizen concerns. Notably, the extensive discussion of radiation has not touched on broadband, though it too could involve radiation emissions, from radio links, satellites, and wireless local networks.

Market actors need to obtain municipal permits to build 3G masts; the municipality, however, has no authority to force market actors to build a $3 \mathrm{G}$ system in their municipality or anywhere else. The action space for local governance is thus much more limited for $3 \mathrm{G}$ than for broadband.

Technical knowledge gives municipal actors an advantage, and has allowed them to coordinate broadband with other technical systems, most commonly with energy systems. This advantage cannot be used in the case of $3 \mathrm{G}$. The traditions of strong municipal autonomy and strong local planning have no scope here. Municipalities' local knowledge and experience, gained from the establishment of other large technical systems, is not seen as valuable in the $3 \mathrm{G}$ context and has not been used. The municipal role in this process is to implement national policy smoothly, despite the fact that when it comes to $3 \mathrm{G}$ they have little scope or policy traction. That fact that different municipalities have different personal, knowledge, economic, and geographic resources has not been highlighted; but despite these differences, the expectation is that systems will be developed in the same way all over the country.

Overall there were few critical problems regarding broadband. However, critical problems occurred in the municipalities where market actors were expected to play a main role. In these cases neither the municipal council nor the administration could take responsibility for coordinating broadband. Municipal government used local knowledge and involved local actors in tight social networks. Potential critical problems were thus transformed into solvable forms by the system builders early in the process, and were no longer considered problems. One reason for this proactive stance is that the municipalities themselves had to handle the establishment of broadband infrastructure. Thus, many of the critical problems can be seen as connected to the local broadband technological style.

\section{“Technology style"}

There were no clear local technology styles regarding $3 \mathrm{G}$ in municipalities, since development of the infrastructure were not in the hands of the municipal democratic bodies. The exception was the mast-free zones declared in some municipalities, mainly motivated by health concerns and fear of radiation. Masts also have to fit into the landscape, and the visual influence on the local environment can be considered in the building permit process. As 
mentioned above, excessive impact on the local environment has been one reason for rejecting building permit applications in Linköping. There was rather a strong market style based on demands expressed by users and potential users. The national policy of allowing only four nationwide operator approvals for building the infrastructure has also created a national technological style.

The citizens have mainly been looked at as users of the systems, to be involved and engaged when the system is built. Citizens' ability to influence localization of $3 \mathrm{G}$ masts was limited and they could mainly delay the expansion, which was a characteristic of the technological style. General awareness of radiation, how and why it was experienced, as a problem among citizens was not taken into consideration. Municipalities and operators tried to find other locations for the masts that would not result in massive protests instead of dealing with the reasons for the protests. Localization of masts in areas with less organized resistance excluded radiation as an issue on the agenda.

Broadband, on the other hand, manifested a clear local technological style. The conditions and resources available to local system builders were arranged in a particular local order that constitutes a local technological style. For example, active local consultants, serving as system builders, were not simply a neutral positive element. Their often close connection to one company also included one particular model of sociotechnical solution. The company's own design and provision of hardware usually defined the local technological style, since they became a resource within the process. Openness and competition in system implementation, central concepts in the national legislation, were not always adequate, since many municipalities lacked the competence to request these of the companies. Most matters of technical competence, which were deciding factors for the local technological style, were decided on within the companies and never became a political issue on the local agenda.

The northernmost Swedish county, Norrbotten, with extremely low population density and long winters, needed a method for installing fiber optic cables even during the winter. The solution was to hang the cable on existing electricity poles. This was a technological style adapted to the climate, which was a crucial aspect of this physical context in the area. During the first winter, however, this solution caused many problems, since the suspension device was dimensioned for the cable, not for the snow and ice that accumulated on it. All suspension devices were replaced already in the end of the winter in May, and a new technological style was developed. Then it was convenient to apply the devices by snow mobiles. This instance of local handling of broadband infrastructure development highlights the importance of openness to local differences. 
In some regions, especially those consisting of very small municipalities, common or joint procurement has been the main factor creating a regional technological style. Common purchasing, however, limits the action space for system builders. Such common procurement was generally arranged through cooperation among a region's municipalities via a specific non-profit organization, such as IT Norrbotten and IT Västerbotten (the latter also includes representatives from the county council), legitimized by the municipalities and other local interests. These regional umbrella organizations have inspired the regional technological style, and their role in linking municipalities and even villages aimed at fitting them into the regional technology style. The national legislation established an overriding policy based on the Swedish technology style, sometimes defined and even limited by regional agreements and cooperation. The municipality itself as result of compromise among former orders, local conditions, and system builders, is what defines the technology style.

We conclude that broadband infrastructure in municipalities has developed clear local technology styles, while $3 \mathrm{G}$ infrastructure was characterized by a single national technology style, with only slight system differences perceptible between operators. Finally, we will also highlight the characteristic differences between technology styles, which have probably both implicitly and explicitly influenced urban technology management. Broadband infrastructure is mainly regarded as opening up opportunities for development, while $3 \mathrm{G}$ infrastructure is regarded as posing a radiation risk.

\section{Concluding remarks}

Municipalities have been granted various responsibilities as well as opportunities in handling these new IT infrastructural establishments. The introduction of $3 \mathrm{G}$ service was treated as a market issue handled by licenses offered by the National Post and Telecom Agency (PTS). The only necessary role of municipal administration in this regard was handling requests for building permits for erecting $3 \mathrm{G}$ masts. Broadband infrastructure was, on the other hand, implemented as a municipal planning issue, according to the municipalities' exclusive planning power. National policies define and distribute broadband subsidies unequally, excluding regions of high growth where market provision was expected. Some municipalities obtain generous partial governmental funding while others have to rely completely on market initiatives and funding. The Swedish infrastructure regime applies on the broadband system, but not to the $3 \mathrm{G}$ system. If the policy for $3 \mathrm{G}$-systems was a consequence of its technical mobile design or global liberal trends of marketization can not be clarified. 
The differences between broadband and $3 \mathrm{G}$ handling are obvious in terms of the three aspects of the development of sociotechnical systems. Many local system builders were involved in the establishment of broadband, but in $3 \mathrm{G}$ development mainly national system builders played roles. In the broadband case the potential critical problems were solved during the policy-making process. The lack of local involvement in the $3 \mathrm{G}$ development process meant that citizen fears of radiation were ignored early on in the design phase, only to surface later on as a main critical problem during implementation. Broadband policy design opened for clear local technology styles adapted to local conditions, something which the $3 \mathrm{G}$ infrastructure technology lacked.

It is obvious that the spatially organized system of broadband provision is regarded as a municipal government responsibility similar to and included in physical planning, while the flexible and mobile $3 \mathrm{G}$ telephone system is instead considered a market issue and not a political responsibility at the local level. We argue that the technological design of these two systems has strongly influenced how the technical infrastructures are governed and thereby implemented locally.

Our analysis indicates that urban governance of information technology in these cases clearly depends on if the technological system is mobile or physical bound. National policies have clearly defined the municipal action space, which is much broader in the broadband than in the $3 \mathrm{G}$ case (regarded nationally as a market issue). Still, both these policy areas were mainly formulated at the national or even European levels; from there, the implementation process flowed onto the urban level and the administrative bodies there. The local legitimate power of the citizens does not influence how technology is formulated, and it can only marginally influence local implementation. The main obligation of the municipalities regarding $3 \mathrm{G}$ was to support the demands of the market actors and of the state (as articulated by PTS). This happened because the $3 \mathrm{G}$ system is considered mobile and thus not as geographically bounded an infrastructure as broadband mainly still is. The physical and geographical bounds of the broadband system were included within the exclusive purview of municipal planning power, thereby becoming a municipal policy issue. The Swedish model of handling infrastructure, as highlighted by Kaijser (1994), is also obvious regarding broadband, but $3 \mathrm{G}$ is uniquely excluded from this model by virtue of the strong positions given to market actors. A reason for this might be the globalized or at least European context of $3 \mathrm{G}$ and its customers. 


\section{References}

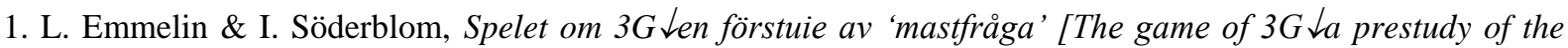
mast issue] (Bleking Institute of Technology, Research Report No 2002:07).

2. Government bill 1999/2000:86, Ett informationssamhälle för alla [An Information Society for everyone].

3. Government bill 2002/03:110, Lag om elektronisk kommunikation m.m. an English Summary available in the information material: Electronic Communications Act. N3012. Also available (2005-07-13) at: http://www.sweden.gov.se/sb/d/2025/a/18454.

4. Government bill 2003/04:136, Ledningsrätt för elektroniska kommunikationsnät[Regulation of electronic communication net].

5. Government bill 2004/05:175, Från IT-politik för samhället till politik för IT-samhället [From IT-policy for society to policy for IT-society].

5a. A. Gullberg and A. Kaijser, "City-Building Regimes in Post-War Stockholm" Journal of Urban Technology 11 (2004) 13-39.

6. T.P. Hughes, Networks of Power: Electrification in Western Society 1880-1930 (Baltimore: John Hopkins University Press, 1983).

7. T.P. Hughes, "The Seamless Web: Technology, Science, etcetera, etcetera," Social Studies of Science 16 (1986).

8. T. Hägerstrand, Time-Geography: Focus on the Corporeality of Man, Society, and Environment (New York: The United Nations University, 1985).

9. T. Hägerstrand, T, "Samhälle och natur" [Society and Nature], in NordREFO 1993:1, Region- och miljöekologiska perspektiv på den rumsliga närings- och bosättningsstrukturen (København: Nordisk Institut for Regionalpolitisk Forskning, 1993).

10. L. Ingelstam, System-att tänka över samhälle och teknik [System-to think over society and technology] (Eskilstuna: Energimyndighetens förlag, 2002).

10a J. Khan, Local Politics of Renewable Energy: Project Planning, siting conflicts and Citizen Participation (Environmental and Energy Systems Studies, Lund University, 2004).

11. A. Kaijser, I Fädrens spår. Den svenska infrastrukturens historiska utveckling och framtida utmaningar. [Swedish infrastructure historical development and future challenges] (Stockholm: Carlssons förlag, 1994).

12. J. Palm, Makten över energin - policyprocesser i två kommuner 1977-2001[Energy Power-policy processes in two municipalities 1977-2001] (Linköpings Studies in Arts and Science no 289, Linköpings universitet, 2004).

13. PTS, UMTS-utbyggnaden [UTMS-expansion](PTS-ER 2005:4, 2005).

14. Socialstyrelsen et.al, [The National Board of Healt and Welfare] Strålning från mobiltelefonsystem. En informationsbroschyr frän sex myndigheter. [Radiation from mobile telephone system. An information leaflet from six authorities] (2002).

15. SFS 1987:10 (Swedish code of statements), Planning and Building Act

16. SFS 1998:808 (Swedish code of statements), The Environmental Code.

17. J. Summerton, District heating comes to town. The Social shaping of an Energy company (Linköping Studies in Arts and Science no 80, Linköpings universitet, 1992).

18. E. Wihlborg, En lösning som söker problem. [A solution looking for problems] (Linköping Studies in Arts and Science no 225, Linköpings universitet, 2000).

19. E. Wihlborg et al (2003) Kommunala Bredbandsbyggen. Lokal politik för IT-samhället [Building Municipal Broadband, Local policy for IT-society], Tema-T Report 40. (Tema Teknik och social förändring, Linköping university, 2003). Also available (2005-07-13) at: http://www.tema.liu.se/tema$\mathrm{t} / \mathrm{mits} /$ publikationer/Kommunala\%20bredbandsbyggen.pdf.

20. S. Woolgar (ed.,) Virtual Society: technology, cyberbole, reality (New York: Oxford University Press, 2002). 